\title{
STUDY OF CRYPTOCOCCAL MENINGITIS IN HIV POSITIVE PATIENTS AT VIMS, BELLARY.
}

Sunil Kumar¹, Madhu K. J².

1. Assistant Professor, Department of Medicine, Vijayanagara Institute of Medical Sciences, Bellary, Karnataka.

2. Assistant Professor, Department of Medicine, Vijayanagara Institute of Medical Sciences, Bellary, Karnataka.

\section{CORRESPONDING AUTHOR}

Dr Sunil Kumar,

Room no 11, 17th Block,

VIMS Campus, (OPD),

Bellary, Pin-583104.

Email-drsunilvims@gmail.com

\section{HOW TO CITE THIS ARTICLE:}

Sunil Kumar, Madhu K. J. "Study of Cryptococcal Meningitis in HIV Positive Patients at VIMS, Bellary". Journal of Evolution of Medical and Dental Sciences 2013; Vol2, Issue 26, July 1; Page: 4840-4851.

ABSTRACT: - BACKGROUND AND OBJECTIVES: Cryptococcal meningitis is a common opportunistic infection and AIDS defining illness in patients with late stage HIV infection, particularly in Southeast Asia and Southern and East Africa. With the increase in the incidence of HIV infection, there is an increase in incidence of cryptococcal meningitis.

Since Vijayanagar institute of medical sciences hospital is a referral center for HIV seropositive patients, the present study was taken up to study the various manifestations of cryptococcal meningitis with respect to its clinical manifestations, diagnostic features, and response to therapy. MATERIAL AND METHODS: All patients who presented with features suggestive of meningitis and a low CD4 count were initially screened for cryptococcal meningitis. 30 HIV seropositive patients who were diagnosed to have Cryptococcal meningitis based on CSF culture of Cryptococcus neoformans were included in the study. RESULTS: Prevalence of cryptococcal meningitis was more in males and most of the patients (75.66\%) were in the age group of 26-40 years. Headache $(90 \%)$, vomiting $(80 \%)$, and fever $(70 \%)$ were the most common presenting symptoms. Mean CD4 Count was $72.33 \pm 5.32$ (range 10-200). . Presenting symptoms in cryptococcal meningitis and mixed infection were similar. Frank meningeal signs, raised CSF proteins, and CSF pleocytosis were significantly more in patients with mixed infection. Altered sensorium, raised CSF cell count, CD4 count of $\leq 50$, papilledema, and presence of meningeal signs was associated with poor prognosis. CONCLUSION: In half of the patients, cryptococcal meningitis was the AIDS defining illness. Majority of the patients had an acute to subacute presentation and India ink negativity does not rule out cryptococcal meningitis.. Response to therapy with Amphotericin B and Fluconazole is well tolerated with a good recovery.

KEY WORDS: Cryptococcal meningitis; Opportunistic infection; AIDS; HIV; Cryptococcus neoformans; Neuro infection; Amphotericin B. 


\section{ORIGINAL ARTICLE}

INTRODUCTION: Cryptococcosis is an infection caused by the yeastlike fungus, Cryptococcus neoformans. Fever and headache in a patient with AIDS or with risk factors for HIV infection suggest the possibility of cryptococcosis. ${ }^{1}$

Cryptococcal meningitis is a common opportunistic infection and AIDS defining illness in patients with late stage HIV infection, particularly in Southeast Asia and Southern and East Africa.1,2,3 With the increase in the incidence of HIV infection, there is an increase in incidence of cryptococcal meningitis. ${ }^{4}$ Cryptococcal neoformans is the leading cause of meningitis in patients with AIDS. ${ }^{5}$

Cryptococcal meningitis also occurs in patients with other forms of immunosuppression and in apparently immunocompetent individuals. Cryptococcal meningitis has been reported as the most common opportunistic infection of the CNS of Indians patients with HIV.6,7,8 Cryptococcal meningitis is now the leading cause of community acquired meningitis, accounting for $20-45 \%$ of laboratory confirmed cases of meningitis in Southern Africa. ${ }^{9}$

It is the initial AIDS defining illness in $\sim 2 \%$ of patients and generally occurs in patients with CD4 counts $<100 / \mu \mathrm{l} .^{10,11}$ Most of the patients have an acute to subacute presentation. Cryptococcosis in AIDS patients is notable for the relative paucity of symptoms and signs, even in severe disease. Headache is present in $\sim 90 \%$ of cases and fever in $\sim 75 \%$. Prostate gland may serve as a reservoir for smoldering cryptococcal infection ${ }^{1}$. Lumbar puncture is the single most useful diagnostic test

Mortality from HIV associated cryptococcal meningitis remains high (10-30\%), even in developed countries, because of the inadequacy of current antifungal drugs and combinations, and the complication of raised intracranial pressure. ${ }^{12}$

In the developing world, patients tend to present later, flucytosine is often not available and there may not be the resources or facilities for inpatient intravenous therapy with amphotericin B. The result of this combination of factors is that in cohorts of HIV-infected patients from sub-Saharan Africa, cryptococcosis has accounted for $13-44 \%$ of all deaths. ${ }^{13}$

However the expansion of antiretroviral programmes now raises the prospect of transforming the long term prognosis of these patients, provided that they survive the acute phase of the illness. ${ }^{10}$

Since Vijayanagar institute of medical sciences hospital is a referral center for HIV seropositive patients after the establishment of antiretroviral therapy center. The number of patients being referred with HIV/AIDS has increased considerably and more and more cases of cryptococcal meningitis are diagnosed.

Hence the present study is taken up to study the various manifestations of cryptococcal meningitis with respect to its clinical manifestations, diagnostic features, and response to therapy.

AIMS AND OBJECTIVES: The present study is undertaken to study Cryptococcal meningitis in HIV seropositive subjects with respect to-

1. Clinical course

2. Laboratory findings like-

- CSF profile

- Radiological profile

- CD4 count

3. Response to treatment. 
4. Prognostic factors.

MATERIAL AND METHODS: - SOURCE OF DATA: 30 patients of Cryptococcal meningitis who were HIV seropositive were studied prospectively at Vijayanagar institute of medical sciences. The study was done over a period of 1 year.

METHOD OF COLLECTION OF DATA: 30 patients of Cryptococcal meningitis who were HIV seropositive were included in the study. A detailed clinical evaluation (history and examination) and relevant laboratory investigations were done for all subjects as per the proforma.

Inclusion criteria: All patients who presented with features suggestive of meningitis and a low CD4 count were initially screened for cryptococcal meningitis. All the HIV seropositive patients who were diagnosed to have Cryptococcal meningitis based on CSF culture of Cryptococcus neoformans were included in the study.

\section{EXCLUSION CRITERIA:}

1. Cryptococcal meningitis in patients who are not HIV seropositive.

2 . Children $<12$ years of age.

\section{INVESTIGATIONS DONE:}

1. ELISA test for HIV

2. CD4 count was determined by BD FACS Count system.

3. CSF analysis for

a. Proteins and sugar

b. Cell count and cell type

c. India ink smear

d. Cryptococcal antigen

e. Cryptococcal culture

4. CT Brain

5. Renal function tests

6. Blood culture (optional)

7. Chest X-ray

STATISTICAL METHODS: Chi-square and Fisher exact test have been used to test the significance of study parameters between Group A and Group B. Odds Ratio has been used to find the strength of relationship between study parameters and the groups. Student t test (independent samples) has been used to find the significance of investigations between the two groups.

1. Chi-Square Test

$\chi^{2}=\frac{\sum(O i-E i)^{2}}{E i}$, Where Oi is observed frequency and Ei is Expected frequency

2. Fisher Exact Test

\begin{tabular}{|l|l|l|l|}
\hline & Class1 & Class2 & Total \\
\hline Sample1 & A & B & $\mathrm{a}+\mathrm{b}$ \\
\hline
\end{tabular}




\begin{tabular}{|l|l|l|l|}
\hline Sample2 & C & D & c+d \\
\hline Total & a+c & b+d & N \\
\hline
\end{tabular}

Fisher Exact Test statistic $=\sum p=\frac{(a+b)(c+d)(a+c)(b+d)}{n} \frac{1}{\sum a b c d}$

3. Odds Ratio OR=ad/bc

4. Student t test (Independent)

Objective: To investigate the significance between the means of two populations

$$
t=\frac{\left(\bar{x}_{1}-\bar{x}_{2}\right)-\left(\mu_{1}-\mu_{2}\right)}{\sqrt{s^{2}(1 / n 1+1 / n 2)}}
$$

Where $s^{2}=\frac{(n 1-1) \sum_{i=1}^{n 1}(x 1-\bar{x} 1)^{2}+(n 2-1) \sum_{i=1}^{n 2}(x 2-\bar{x} 2)^{2}}{n 1+n 2-2}$

STATISTICAL SOFTWARE: The Statistical software namely SPSS 11.0 and Systat 8.0 were used for the analysis of the data and Microsoft word and Excel have been used to generate graphs, tables etc.

RESULTS AND OBSERVATIONS: Results are as shown in the tables

DISCUSSION: - AGE: In the present study the mean age of patients was 33.55 years, Most of the patients $(76.66 \%)$ were in the age group between 26 and 40 years.. This is in accordance with the study done by Imwidthaya $\mathrm{P}$ et $\mathrm{al}^{20}{ }^{20}$ where the mean age of patients was 32.1 years.

Sex: In the present study, the number of males was more as compared to the number of females $(25$ Vs 5). In the study done by Imwidthaya $P$ et $a l, 2080.46 \%$ of the patients were males.

Duration of HIV seropositive status: Cryptococcal meningitis was the first manifestation of AIDS in $46.66 \%$ of the patients. This finding is similar to the study done by Chuck SL et al, ${ }^{14}$ wherein cryptococcal meningitis was AIDS defining illness in $45.28 \%$ of the patients..

Presenting symptoms: In the present study headache, vomiting and fever were the most common presenting symptoms. In the study done by Woldemanuel Y et al ,22 fever and headache were the most common presenting symptoms.

\section{TABLE 15: COMPARISION OF PRESENTING SYMPTOMS WITH OTHER STUDIES}

\begin{tabular}{|l|l|l|l|l|l|}
\hline $\begin{array}{l}\text { Presenting } \\
\text { symptoms }\end{array}$ & $\begin{array}{l}\text { Chuck SL et } \\
\text { al14 }(\mathrm{n}=106)\end{array}$ & $\begin{array}{l}\text { Martinez } \\
\text { Fernandez } \\
\text { EM et al 21 } \\
(\mathrm{n}=25)\end{array}$ & $\begin{array}{l}\text { Darras-Joly C } \\
\text { et al23 (n=65) }\end{array}$ & $\begin{array}{l}\text { Kalra SP et } \\
\text { al24 (n=15) }\end{array}$ & $\begin{array}{l}\text { Present } \\
\text { study } \\
(\mathrm{n}=30)\end{array}$ \\
\hline Headache & $73 \%$ & $88 \%$ & $67 \%$ & $80 \%$ & $90 \%$ \\
\hline Vomiting & $42 \%$ & - & - & - & $80 \%$ \\
\hline Fever & $45 \%$ & $68 \%$ & $86 \%$ & $86.6 \%$ & $70 \%$ \\
\hline $\begin{array}{l}\text { Altered } \\
\text { sensorium }\end{array}$ & $28 \%$ & - & $29 \%$ & $26.6 \%$ & $30 \%$ \\
\hline Seizures & - & $20 \%$ & - & - & $10 \%$ \\
\hline
\end{tabular}


MENINGEAL SIGNS: In the present study $83.33 \%$ of the patients had meningeal signs. Frank meningeal signs were present only in $33.33 \%$ of the patients. This is in accordance with the study done by Mwaba $\mathrm{P}$ et al, ${ }^{16}$ where $85 \%$ of the patients had meningeal signs. Maher $\mathrm{D}$ et al, ${ }^{25}$ noted that $74 \%$ of the patients with cryptococcal meningitis had meningeal signs.

CSF INDIA INK, CRYPTOCOCCAL ANTIGEN, And CRYPTOCOCCAL CULTURE POSITIVITY: CSF India ink was positive in $90 \%$ of the patients. In all the 30 patients, CSF cryptococcal antigen and CSF cryptococcal culture was positive.

TABLE 16: COMPARISION OF CSF INDIA INK, CRYPTOCOCCAL ANTIGEN, AND CRYPTOCOCCAL CULTURE POSITIVITY WITH OTHER STUDIES

\begin{tabular}{|l|l|l|l|l|}
\hline & $\begin{array}{l}\text { Imwidthaya P et } \\
\mathrm{al}^{20}(\mathrm{n}=87)\end{array}$ & $\begin{array}{l}\text { Darras-Joly C et } \\
\mathrm{al}^{23}(\mathrm{n}=65)\end{array}$ & $\begin{array}{l}\text { Khanna N et } \\
\mathrm{al}^{25}(\mathrm{n}=87)\end{array}$ & $\begin{array}{l}\text { Present study } \\
(\mathrm{n}=30)\end{array}$ \\
\hline $\begin{array}{l}\text { CSF India Ink } \\
\text { positivity }\end{array}$ & $91 \%$ & $87 \%$ & $87.36 \%$ & $90 \%$ \\
\hline $\begin{array}{l}\text { CSF } \\
\text { Cryptococcal } \\
\text { antigen } \\
\text { positivity }\end{array}$ & $100 \%$ & $92 \%$ & $98.81 \%$ & $100 \%$ \\
\hline $\begin{array}{l}\text { CSF } \\
\text { Cryptococcal } \\
\text { culture } \\
\text { positivity }\end{array}$ & $100 \%$ & $100 \%$ & $100 \%$ & $100 \%$ \\
\hline
\end{tabular}

India ink preparation is a simple procedure and it is used as a screening procedure in cases of cryptococcal meningitis. The positivity in the present study with respect to India ink preparation is similar to studies done by Imwidthaya $\mathrm{P}$ et al, ${ }^{20}$ Darras-Joly $\mathrm{C}$ et al, ${ }^{23}$ and Khanna $\mathrm{N}$ et al. $^{26}$

The CSF culture for Cryptococcus neoformans is diagnostic test, hence all the studies cited above have $100 \%$ positivity. There is a high correlation between the culture positivity and the presence of cryptococcal antigen in the CSF. Present study correlates with study done by Imwidthaya $\mathrm{P}$ et $\mathrm{al},{ }^{20}$ whereas in the study done by Darras-Joly $\mathrm{C}$ et $\mathrm{al}^{21}$ the cryptococcal antigen positivity was less compared to the present study.

CSF GLUCOSE LEVELS: In the present study the mean CSF glucose level was $45.63 \mathrm{mg} / \mathrm{dl}$ and $53.32 \%$ of the patients had a CSF glucose level of $<40 \mathrm{mg} / \mathrm{dl}$. In the study done by Hakim et al, $952.7 \%$ of the patients had a CSF glucose level of $<40 \mathrm{mg} / \mathrm{dl}$.

Because of minimal cellular inflammation of meninges, CSF glucose levels are not grossly decreased. This correlates with other studies.

CSF PROTEIN LEVELS: In the present study the mean CSF protein level was $106.33 \mathrm{mg} / \mathrm{dl}$ and $93.34 \%$ of the patients had a CSF protein level of $>40 \mathrm{mg} / \mathrm{dl}$. This is in accordance with the study 


\section{ORIGINAL ARTICLE}

done by Hakim et al, ${ }^{9}$ where $80.6 \%$ of the patients had a CSF protein level of $>40 \mathrm{mg} / \mathrm{dl}$. Mildly raised CSF proteins is a common finding in patients with cryptococcal meningitis

CD4 COUNT: In the present study mean CD4 Count was 72.33. In the study done by Imwidthaya P et al, ${ }^{20}$ mean CD4 Count was 45. In another study done by Darras-Joly C et al,23 mean CD4 Count was 46. In the present study, all the 30 patients $(100 \%)$ had a CD4 count of $<200$. Martinez Fernandez EM et $\mathrm{al}^{21}$ noted that $84 \%$ of the patients had a CD4 count of $<200.56 .66 \%$ of the patients in the present study had a CD 4 count of $<50$. In the study done by Bava AJ et al, ${ }^{20} 83.63 \%$ of the patients had a CD 4 count of $<50$. This is in accordance with the observation that cryptococcal meningitis presents in late stage of HIV infection; and lower the CD4 count, higher the occurrence of cryptococcal meningitis.

MORTALITY: In the present study mortality was 33.33\%. In the study done by Khanna $\mathrm{N}$ et al, ${ }^{26}$ mortality was $32.18 \%$. Mortality was $36.7 \%$ in the study done by Metta HA et al. ${ }^{27}$ Mortalility in cryptococcal meningitis is high and it is mainly due to the immunodeficiency seen in the patients. In the present study the mortality was slightly less compared to the study done by Khanna $\mathrm{N}$ et al ${ }^{26}$ and Metta HA et al. ${ }^{61} \mathrm{As}$ all the patients were put on Amphotericin B and fluconazole, there is a better prognosis seen in present study compared to the above two studies.

POOR PROGNOSTIC FACTORS: In the present study the poor prognostic factors included altered sensorium, raised CSF cell count, CD4 count of $\leq 50$, papilledema, and presence of meningeal signs. Altered sensorium was a significant predictor of bad prognosis (death). Altered sensorium was 14.28 times more likely to predict death. This is concordance with various other studies which have shown that altered sensorium is associated with poor prognosis. ${ }^{15,17,18}$ Raised CSF cell count $(>5$ cells) was 3.58 times more likely to predict death. A CD4 count of $\leq 50$ was 3.40 times more likely to predict death. This is in concordance with study done by Robinson PA et al. ${ }^{19}$

SUMMARY: The present study was undertaken to study the Clinical course, Laboratory findings, outcome, and prognostic factors in HIV seropositive patients with Cryptococcal meningitis. For this, 30 HIV seropositive patients with cryptococcal meningitis were randomly selected.

Review of literature regarding cryptococcal meningitis in HIV positive patients was done. Present study was viewed in comparison with other national and international studies. The salient features of this study are-

1. Prevalence of cryptococcal meningitis was more in males.

2. Most of the patients were in the age group of 26-40 years.

3. Majority of patients had an acute to subacute presentation.

4. In half of the patients, cryptococcal meningitis was the first manifestation of AIDS.

5. Headache, vomiting, and fever were the most common presenting symptoms.

6. CSF India Ink was positive in $90 \%$ of the patients only.

7. Most of the patients had a CD4 count of $<100 / \mu$.

8. Disseminated Cryptococcemia was not common.

9. Presenting symptoms in cryptococcal meningitis and mixed infection were similar.

10. Frank meningeal signs were significantly more in patients with mixed infection.

11. Altered sensorium, raised CSF cell count, CD4 count of $\leq 50$, papilledema, and 


\section{ORIGINAL ARTICLE}

12. Presence of meningeal signs was associated with poor prognosis.

13. Reinfection was seen in $4.29 \%$ of the patients.

14. Cryptococcal meningitis due to Immune reconstitution syndrome was seen in $5.71 \%$ of the patients.

15. Response to therapy with Amphotericin B and Fluconazole was good and recovery was seen in $71.4 \%$ of the patients.

16. All survivors were subsequently started on HAART.

Statistical analysis was done as per research guidelines. Vancouver format was used in writing bibliography. Master chart reveals all patient data.

\section{BIBLIOGRAPHY}

1. Casadell arturo; Cryptococcosis; Harrison's principle of internal medicine,17thedition, Anthony s fauci, Eugene Braunwald, Dennis L. kasper, Stephen L hauser, Dan L. longo, et al, Mc graw hill, 2008,1251

2. Chuck sl, Sande ma: Infection with Cryptococcus neoformans in the acquired immunodeficiency syndrome. N Engl J Med, 1989. 321:794

3. Holmes CB, Losina E, Walensky RP, Yazdanpanah Y, Freedberg KA. Review of human immunodeficiency virus type 1- related opportunistic infections in Sub-Saharan Africa. Clin Infect Dis. 2003; 36:652-62.

4. Currie BP, Casadevall A. Estimation of the prevalence of cryptococcal infection among patients infected with human immunodeficiency virus in New York City. Clin Infect Dis. 1994 Dec; 19(6):1029-33.

5. Helbol R, Pongpakdee S, Yenjun S, Dent W, Beer R, Lackner P et al. Chronic meningitis in Thailand, Clinical characteristics, laboratory data \& outcome in patients with specific reference to tuberculosis \& cryptococcosis. Neuro epidemiology. 2006; 26(1):37-44.

6. Wadia RS, Pujari SN, Kothari S, Udhar M, Kulkarni S, Bhagat S et al. Neurological manifestations of HIV disease. J Assoc Physicians India. 2001; 49:343-8.

7. Satishchandra P, Nalini A, Gourie-Devi M, Khanna N, Santosh V, Ravi V et al. Profile of neurologic disorders associated with HIV/AIDS from Bangalore, south India (1989-96). Indian J Med Res. 2000; 111:14-23.

8. Aquinas SR, Tarey SD, Ravindran GD, Nagamani D, Ross C. Cryptococcal meningitis in AIDSneed for early diagnosis. J Assoc Physicians India. 1996 Mar; 44(3):178-80.

9. Hakim JG, Gangaidzo IT, Heyderman RS, Mielke J, Mushange E, Taziwa A et al. Impact of HIV infection on meningitis in Harare, Zimbabwe: a prospective study of 406 predominantly adult patients. AIDS. 2000; 14(10):1401-7.

10. Powderly WG. Current Approach to the Acute Management of Cryptococcal Infections. Journal of Infection .2000; 41:18-22.

11. Powderly WG. Cryptococcal meningitis and AIDS. Clin Infect Dis. 1993 Nov; 17(5):837-42.

12. Van der Horst CM, Saag MS, Cloud GA, Hamill RJ, Graybill JR, Sobel JD et al. Treatment of cryptococcal meningitis associated with the acquired immunodeficiency syndrome. $N$ Engl J Med. 1997; 337:15-21.

13. French N, Gray K, Watera C, Nakiyingi J, Lugada E, Moore $\mathrm{M}$ et al. Cryptococcal infection in a cohort of HIV-1 infected Ugandan adults. AIDS. 2002; 16(7):1031-8. 


\section{ORIGINAL ARTICLE}

14. 14 Chuck SL, Sande MA. Infections with cryptococcus neoformans in the acquired Immunodeficiency syndrome. N Engl J Med. 1989 Sep 21; 321(12):794-9

15. 15 Clark RA, Greer D, Atkinson W, Valainis GT, Hyslop N. Spectrum of cryptococcus neoformans infection in 68 patients infected with human immunodeficiency virus. Rev Infect Dis. 1990; 12(5):768-77

16. 16 Mwaba P, Mwansa J, Chintu C, Pobee J, Scarborough M, Portsmouth S et al. Clinical presentation, natural history, and cumulative death rates of 230 adults with primary cryptococcal meningitis in Zambian AIDS patients treated under local conditions. Postgrad Med J. 2001; 77:769-73.

17. 17 Brouwer AE, Rajanuwong A, Chierakul W, Griffin GE, Larsen RA, White NJ et al. Combination antifungal therapies for HIV associated Cryptococcal meningitis: a randomized trial. Lancet. 2004;363:1764-7

18. Saag MS, Powderly WG, Cloud GA, Robinson P, Grieco MH, Sharkey PK et al. Comparison of Amphotericin B with Fluconazole in the treatment of acute AIDS- associated Cryptococcal meningitis. The NIAID Mycoses study group and AIDS clinical trial groups. $N$ Engl J Med. 1992; 326(2):83-9.

19. Robinson PA, Bauer M, Leal MA, Evans SG, Holtom PD, Diamond DA et al. Early mycological treatment failure in AIDS-associated Cryptococcal meningitis. Clin Infect Dis. 1999; 28(1):8292.

20. Imwidthaya P, Pougvarin N. Cryptococcosis in AIDS. Postgrad Med J. 2000; 76:85-8.

21. Martinez-Fernandez EM, Lopez-Cortes LF, Regordan C, Cordero-Matia E. Meningitis by Cryptococcus neoformans in patients with HIV infection. Neurologia. 1999 May; 14 (5):21823.

22. Woldemanuel Y, Haile T. Cryptococcosis in patients from Tikur Anbessa Hospital, Addis Ababa, Ethiopa. Ethiop Med J. 2001 Jul; 39(3):185-92.

23. Darras-Joly C, Chevret S, Wolff M, Matheron S, Longuet P, Casalino E et al. Cryptococcus neoformans infection in France: epidemiologic features of and early prognostic parameters for 76 patients who were infected with human immunodeficiency virus. Clin Infect Dis. 1996 Aug; 23(2):369-76.

24. Kalra SP, Chadha DS, Singh AP, Sanchetee PC, Mohapatra AK. Cryptococcal meningitis in acquired immunodeficiency syndrome. J Assoc Physicians India. 1999 Oct; 47(10):958-61.

25. Maher D, Mwandumba H. Cryptococcal meningitis in Lilongwe and Blantyre, Malawi. J Infect. 1994 Jan;28(1):59-64.

26. Khanna N, Chandramukhi A, Desai A, Ravi V, Santosh V, Shankar SK et al. Cryptococcosis in the immunocompromised Host with special reference to AIDS. Indian J Chest Dis Allied Sci. 2000; 42(4):311-5.

27. Metta HA, Corti ME, Negroni R, Helou S, Arechavala A, Soto I et al. Disseminated cryptococcosis in patients with AIDS. Clinical, microbiological, and immunological analysis of 51 patients. Rev Argent Microbiol. 2002 Jul-Sep; 34(3):117-23. 


\section{ORIGINAL ARTICLE}

\section{RESULTS AND OBSERVATIONS: TABLE 1: AGE DISTRIBUTION}

\begin{tabular}{|l|l|}
\hline Age in years & Number of patients \\
\hline $20-25$ & $4(13.33 \%)$ \\
\hline $26-30$ & $6(20 \%)$ \\
\hline $31-35$ & $10(33.33 \%)$ \\
\hline $36-40$ & $7(23.33 \%)$ \\
\hline $41-45$ & $2(6.66 \%)$ \\
\hline $46-50$ & $1(3.33 \%)$ \\
\hline Total & 30 \\
\hline Mean \pm SD & $33.55 \pm 7.002$ \\
\hline
\end{tabular}

TABLE 2: GENDER DISTRIBUTION

\begin{tabular}{|l|l|}
\hline Gender & Number of patients $(n=30)$ \\
\hline Male & $25(83.0 \%)$ \\
\hline Female & $5(17 \%)$ \\
\hline
\end{tabular}

TABLE 3: DURATION OF HIV POSITIVE STATUS

\begin{tabular}{|l|l|}
\hline HIV positive status since & Number of patients (n=30) \\
\hline Freshly detected & $14(46.66 \%)$ \\
\hline$<6$ months & $7(23.33 \%)$ \\
\hline $6-12$ months & $4(13.33 \%)$ \\
\hline$>12$ months & $5(16.66 \%)$ \\
\hline
\end{tabular}

TABLE 4: PRESENTING SYMPTOMS

\begin{tabular}{|l|l|}
\hline Symptoms & Number of patients $(n=30)$ \\
\hline Headache & $27(90 \%)$ \\
\hline Vomiting & $24(80 \%)$ \\
\hline Fever & $21(70 \%)$ \\
\hline Altered sensorium & $9(30 \%)$ \\
\hline Seizures & $3(10 \%)$ \\
\hline
\end{tabular}


TABLE 5: DURATION OF NEUROLOGICAL SYMPTOMS

\begin{tabular}{|l|l|}
\hline Duration of symptoms in days & Number of patients (n=30) \\
\hline Up to 15 & $14(46.66 \%)$ \\
\hline $16-30$ & $7(23.33 \%)$ \\
\hline $30-60$ & $6(20 \%)$ \\
\hline$>60$ & $3(10 \%)$ \\
\hline
\end{tabular}

TABLE 6: LEVEL OF CONSCIOUSNESS

\begin{tabular}{|l|l|}
\hline Consciousness & Number of patients $(n=30)$ \\
\hline Conscious & $20(66.66 \%)$ \\
\hline Drowsy & $6(20 \%)$ \\
\hline Comatose & $4(13.33 \%)$ \\
\hline
\end{tabular}

TABLE 7: MENINGEAL SIGNS

\begin{tabular}{|l|l|}
\hline Meningeal signs & Number of patients $(\mathrm{n}=30)$ \\
\hline Absent & $5(16.66 \%)$ \\
\hline Terminal neck stiffness & $15(50 \%)$ \\
\hline Frank meningeal signs & $10(33.33 \%)$ \\
\hline
\end{tabular}

TABLE 8: PERCENTAGE OF CSF INDIA INK, CSF CRYPTOCOCCAL ANTIGEN AND CSF CRYPTOCOCCAL CULTURE POSITIVITY

\begin{tabular}{|l|l|}
\hline CSF findings & Number of patients $(\mathrm{n}=30)$ \\
\hline CSF India Ink positivity & $27(90.0 \%)$ \\
\hline CSF Cryptococcal antigen positivity & $30(100.0 \%)$ \\
\hline CSF Cryptococcal culture positivity & $30(100.0 \%)$ \\
\hline
\end{tabular}




\section{ORIGINAL ARTICLE}

\section{TABLE 9: CSF GLUCOSE LEVELS}

\begin{tabular}{|l|l|}
\hline Glucose levels in mg/dl & Number of patients $(\mathrm{n}=30)$ \\
\hline $0-20$ & $2(6.66 \%)$ \\
\hline $21-40$ & $14(46.66 \%)$ \\
\hline $41-60$ & $10(33.33 \%)$ \\
\hline$>60$ & $4(13.33 \%)$ \\
\hline Mean & 45.63 \\
\hline
\end{tabular}

TABLE 10: CRYPTOCOCCAL BLOOD CULTURE AND BLOOD CRYPTOCOCCAL ANTIGEN POSITIVITY

\begin{tabular}{|l|l|}
\hline Blood test & Number of patients $(\mathrm{n}=30)$ \\
\hline Blood Cryptococcal antigen positivity & $18(60.0 \%)$ \\
\hline Cryptococcal Blood Culture positivity & $10(33.33 \%)$ \\
\hline
\end{tabular}

TABLE 10: CD4 COUNT

\begin{tabular}{|l|l|}
\hline CD4 count & Number of patients $(n=30)$ \\
\hline $0-50$ & $17(56.66 \%)$ \\
\hline $51-100$ & $8(26.66 \%)$ \\
\hline $101-200$ & $5(16.66 \%)$ \\
\hline Mean & 72.33 \\
\hline
\end{tabular}

\section{TABLE 11: CT BRAIN}

\begin{tabular}{|l|l|}
\hline CT brain & Number of patients $(n=30)$ \\
\hline Normal & $10(33.33 \%)$ \\
\hline Diffuse cerebral atrophy & $13(43.33 \%)$ \\
\hline Diffuse cerebral atrophy with ventricular dilation & $7(23.33 \%)$ \\
\hline
\end{tabular}




\section{ORIGINAL ARTICLE}

TABLE 12: OUTCOME

\begin{tabular}{|l|l|}
\hline Outcome & Number of patients $(n=30)$ \\
\hline Dead & $10(33.33 \%)$ \\
\hline Alive & $20(66.66 \%)$ \\
\hline
\end{tabular}

TABLE 13: RISK FACTORS ASSOCIATED WITH DEATH

\begin{tabular}{|l|l|l|l|l|}
\hline \multirow{2}{*}{ Risk factors } & \multicolumn{2}{l}{ Improved (n=20) } & \multicolumn{2}{l|}{ Dead (n=10) } \\
\cline { 2 - 6 } & Number & $\%$ & Number & $\%$ \\
\hline Duration of neurological symptoms (<7 days) & 4 & 20 & 3 & 30 \\
\hline Altered sensorium & 2 & 10 & 7 & 70.0 \\
\hline Presence of meningeal signs & 16 & 80 & 9 & 90 \\
\hline Presence of Papilledema & 5 & 25 & 3 & 30 \\
\hline CSF protein $(>40 \mathrm{mg} /$ dl) & 19 & 95 & 9 & 90 \\
\hline CSF cell count (>5) & 13 & 65 & 7 & 70 \\
\hline CD4 count $\leq 50$ & 10 & 50.0 & 7 & 70 \\
\hline Abnormal CT brain & 13 & 65 & 7 & 70.0 \\
\hline
\end{tabular}

TABLE 14: ANALYSIS OF MULTIVARIATE LOGISTIC REGRESSION TO FIND THE EFFECT OF POOR PROGNOSTIC FACTORS FOR PREDICTING THE DEATH $(\mathrm{N}=30)$

\begin{tabular}{|l|l|l|l|l|l|}
\hline Prognostic factors & $\begin{array}{l}\text { Logistic } \\
\text { efficient }\end{array}$ & $\begin{array}{l}\text { co- } \\
\text { Etandard } \\
\text { Error }\end{array}$ & Wald & $\begin{array}{l}\text { P } \\
\text { value }\end{array}$ & $\begin{array}{l}\text { Adj. } \\
\text { OR }\end{array}$ \\
\hline $\begin{array}{l}\text { Duration of neurological symptoms }(<7 \\
\text { days) }\end{array}$ & -0.01 & 0.98 & 0.00 & 0.989 & 0.99 \\
\hline Altered sensorium & 2.66 & 0.76 & 12.13 & $<0.001$ & 14.28 \\
\hline Presence of meningeal signs & 0.23 & 1.22 & 0.03 & 0.853 & 1.25 \\
\hline Presence of Papilledema & 0.29 & 0.92 & 0.10 & 0.752 & 1.34 \\
\hline CSF protein (>40mg/dl) & -0.60 & 0.94 & 0.40 & 0.528 & 0.55 \\
\hline CSF cell count (>5) & 1.28 & 0.89 & 2.05 & 0.152 & 3.58 \\
\hline CD4 count $\leq 50$ & 1.22 & 0.71 & 2.97 & 0.085 & 3.40 \\
\hline Abnormal CT brain & -1.04 & 0.80 & 1.67 & 0.196 & 0.35 \\
\hline
\end{tabular}

